\title{
Hyaline Cast Measurement
}

National Cancer Institute

\section{Source}

National Cancer Institute. Hyaline Cast Measurement. NCI Thesaurus. Code C74770.

The determination of the amount of hyaline casts present in a urine sample. 